\title{
Perbandingan Jenis Cairan Rehidrasi terhadap Tingkat Dehidrasi dan VO2 Maksimal pada Remaja Putri Peserta Ekstrakurikuler Bola \\ Basket
}

\author{
Choirun Nissa $^{1^{*}}$ Indah Juliana Madjid ${ }^{1}$, Ferdian Hapreda Januardo ${ }^{1}$ \\ ${ }^{1}$ Prodi S1 Ilmu Gizi STIKes Widya Cipta Husada \\ *email: choirunnissa88@gmail.com
}

\section{ABSTRACT}

Indonesia currently tends to have fluctuative achievement in sports, especially in basketball. The sports performance can be affected by several things, which are related to the fulfillment of nutritional adequacy. Balance of fluid is one of essential intakes for athletes. This study aimed to analyze the comparison of rehydration fluids type to dehydration level and vo2max on female teens of basketball extracurricular participants.

This study design was quasy experiment with posttest only group design. The treatments in this study were divided into 3 groups, the first is water-given group, the second water-CHO 6\%-given group and the third is isotonic water-given group. All treatments were performed to 8 female teens of basketball extracurricular participants on the different days.

The results of Kruskal-Wallis statistical test showed difference in the level of dehydration in a variety of treatments $(p=0.0001)$. Based One Way Anova there were no differences in the various treatments VO2max $(p=0.180)$. The conclusion of this research was that providing isotonic water could help reach the best level of hydration for an athlete during training.

Key words: Dehydration Level, VO2max, Rehydration Fluid

Submitted : 2020-12-15 Accepted : 2021-05-04 Published :2021-11-08 
PENDAHULUAN

Prestasi olahraga di Indonesia saat ini cenderung mengalami pasang surut serta tidak stabil dan terkontrol, bahkan dalam acara Sea Games tahun 2015 di Singapura merupakan pencapaian terburuk setelah tahun 2005. (Nigara, 2015)

Prestasi bola basket Indonesia dapat dikatakan mengalami pasang surut di ajang Internasional. Pencapaian prestasi tim nasional basket putri di ajang Sea Games 2015 mampu membawa pulang medali perak setelah terakhir membawa pulang medali pada tahun 1997. (Abdullah, 2015)

Prestasi atlet dapat dipengaruhi beberapa faktor, selain berkaitan dengan proses latihan adalah pemenuhan kecukupan gizi dari atlet. Salah satu unsur gizi yang penting adalah pemenuhan cairan. Konsumsi cairan yang tidak cukup dapat mengakibatkan kelelahan yang akhirnya mempengaruhi performa dan prestasi atlet. (Putriana dan Dieny, 2014)

Dehidrasi yang diikuti dengan gangguan pernafasan dan heat stroke merupakan tanda bahwa tubuh mengalami ketidakseimbangan zat elektrolit dalam tubuh. Salah satu upaya untuk menanggulangi ketidakseimbangan zat elektrolit dalam tubuh adalah dengan mengkonsumsi minuman isotonik atau sport drink. (Nauli, 2006)
Pengeluaran cairan yang tidak diimbangi dengan asupan cairan yang cukup dapat mempengaruhi daya tahan tubuh sehingga berdampak pada prestasi atlet. Penurunan cairan dalam tubuh lebih dari $2 \%$ mampu menyebabkan penurunan performa sebanyak 10\%. (Alim, 2012)

Pemilihan jenis cairan rehidrasi juga mempengaruhi keadaan dehidrasi dari atlet tersebut. Pemilihan yang tepat dapat meminimalisir kejadian dehidrasi sehingga atlet dapat memberikan performa atau kemampuan terbaiknya selama kegiatan olahraga berlangsung, baik ketika latihan maupun bertanding.

Olahraga bola basket merupakan olahraga yang memiliki intensitas sedang atau olahraga ketahanan (endurance). Intensitas yang sedang dalam olahraga bola basket dapat mengakibatkan kelelahan pada atlet setelah pertandingan berakhir. Dehidrasi yang terjadi saat berolahraga dapat menyebabkan penurunan kemampuan konsentrasi, kecepatan reaksi, peningkatan suhu tubuh dan menghambat laju produksi energi sehingga akan berpegaruh terhadap penurunan ketahanan tubuh atau VO2 maksimal. (Alim, 2012)

Tingkat dehidrasi dan kemampuan seorang atlet juga dipengaruhi oleh tingkat VO2 maksimal. Tingkat VO2 maksimal akan menentukan seberapa besar atlet tersebut mampu bertahan 
dalam olahraga ketahanan (endurance). Berdasarkan hal tersebut peneliti ingin membandingkan jenis cairan rehidrasi terhadap tingkat dehidrasi dan $\mathrm{VO} 2$ maksimal pada remaja putri peserta ekstrakurikuler bola basket.

\section{METODE PENELITIAN}

Penelitian ini merupakan penelitian kuantitatif dengan menggunakan quasy experiment rancangan posttest only group design. Penelitian dilaksanakan di SMKN 2 Kediri, Kota Kediri. Subjek dalam penelitian ini adalah semua remaja putri peserta ekstrakurikuler bola basket dan bersedia menjadi subjek penelitian berjumlah 10 remaja putri dengan 2 remaja putri termasuk dalam kategori eksklusi, sehingga didapatkan sampel penelitian sebanyak 8 remaja putri. Perlakuan yang digunakan dalam penelitian ini sebanyak 3 perlakuan, yaitu: P1 (air biasa), P2 (air gula 6\%), P3 (air kelapa hijau muda) diberikan dengan jeda waktu perlakuan 24 jam.

\section{Pengukuran tingkat dehidrasi}

Tingkat dehidrasi yang digunakan berdasarkan perubahan berat badan sebelum dan sesudah perlakuan. Bahan yang digunakan, yaitu: timbangan berat badan digital 0,1 kg. Tingkat dehidrasi dihitung sebagai berikut: perubahan berat badan $=[$ (berat badan sebelum latihan - berat badan setelah latihan)/ berat badan sebelum latihan] x 100 . Kriteria tingkat dehidrasi yaitu +1 sampai -1 (well hydrated); -1 sampai -3 (minimal dehydration); -3 sampai -5 (significant dehydration); < -5 (serious dehydration). (Casa et al., 2000)

\section{Pengukuran VO2 maksimal}

Nilai VO2 maksimal didapatkan melalui beeptest atau multistage fitnes test. Tes ini dilakukan dengan cara tiap responden akan berlari sejauh 20 meter secara bolak balik, setiap responden diharapkan untuk sampai ke ujung yang bertepatan dengan bunyi dari kaset $m p 3$, peserta yang tidak kuat akan diberhentikan. Terdapat 21 tingkatan dengan 16 balikan pada tes ini, semakin tinggi tingkatannya maka semakin baik. Level tertinggi yang dapat dicapai tiap responden sebelum gagal harus dicatat sebagai skor. (Agus, 2012)

Bahan yang digunakan dalam pengukuran VO2 maksimal, diantaranya: speaker, file mp3 beeptest, cone pembatas dan measuring tape $20 \mathrm{~m}$. Kriteria yang digunakan yaitu >49,00 (Tinggi); 38,00 - 48,00 (Bagus); 31,00 - 37,00 (Cukup); 24,00 - 30,00 (Sedang); <23,00 (Rendah). (Agus, 2012) 


\section{Penyajian data}

Data disajikan dalam bentuk angka dan dianalisis menggunakan uji KruskallWallis, Mean-Whitney dan One Way Anova. Data dikatakan memiliki perbedaan apabila nilai $p<0,05$.

\section{HASIL DAN PEMBAHASAN}

\section{Karakteristik subjek penelitian}

Subjek penelitian ini adalah remaja putri peserta ekstrakurikuler bola basket yang memenuhi kriteria penelitian sebanyak 8 remaja putri dengan sebaran umur dari $15 \pm 0,44$ tahun. Median berat

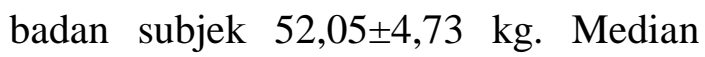
tinggi badan subjek $157,5 \pm 5,52 \mathrm{~cm}$. Ratarata Indeks Massa Tubuh (IMT) subjek $21,49 \pm 1,42 \mathrm{~kg} / \mathrm{m} 2$. Berdasarkan tabel 1 dapat disimpulkan bahwa data usia, berat badan, tinggi badan dan IMT subjek homogen sehingga dapat dilakukan uji lanjutan (tabel 1).

Tabel 1. Karakteristik Subjek berdasarkan Usia, Berat Badan, Tinggi Badan dan IMT

\begin{tabular}{cccccc} 
& $\mathrm{N}$ & $\begin{array}{c}\text { Uji } \\
\text { normalitas }\end{array}$ & Mean \pm SD & Median \pm SD & $\begin{array}{c}\text { Uji } \\
\text { Homogenitas }\end{array}$ \\
\hline Usia (tahun) & 8 & 0,000 & - & $15,00 \pm 0,44$ & 1,00 \\
Berat badan $(\mathrm{kg})$ & 8 & 0,036 & - & $52,05 \pm 4,73$ & 0,993 \\
Tinggi badan $(\mathrm{cm})$ & 8 & 0,005 & - & $157,50 \pm 5,52$ & 1,00 \\
IMT $\left(\mathrm{kg} / \mathrm{m}^{2}\right)$ & 8 & 0,285 & $21,49 \pm 1,42$ & - & 0,982 \\
\hline
\end{tabular}

\section{Tingkat Dehidrasi Remaja Putri Pada Setiap Perlakuan}

Tingkat dehidrasi pada perlakuan 1 berkisar -1,43 sampai -0,93 denngan nilai median sebesar $-1,07$, pada perlakuan 2 berkisar -1,08 sampai -0,43 dengan nilai median sebesar -0,64 dan pada perlakuan 3 berkisar -0,72 sampai 0,64 dengan nilai median sebesar -0,30. Berdasarkan ketiga perlakuan yang telah dilakukan, pemberian cairan rehidrasi paling baik diperoleh pada perlakuan 3 dengan nilai median $-0,30$ (tabel 2).
Tabel 2. Tingkat dehidrasi remaja putri peserta ekstrakurikuler bola basket pada setiap perlakuan

\begin{tabular}{lllll}
\hline Dehidrasi & $\mathrm{N}$ & Median & Minimum & Maximum \\
\hline Perlakuan 1 & 8 & $-1,07$ & $-1,43$ & $-0,98$ \\
Perlakuan 2 & 8 & $-0,64$ & $-1,08$ & $-0,43$ \\
Perlakuan 3 & 8 & $-0,30$ & $-0,72$ & 0,64 \\
Total & 24 & & & \\
\hline
\end{tabular}

Keterangan :

Perlakuan $1=$ Pemberian air biasa

Perlakuan $2=$ Pemberian air karbohidrat $6 \%$

Perlakuan 3 = Pemberian air kelapa muda

\section{Tingkat VO2 Maksimal Remaja Putri}

\section{Pada Setiap Perlakuan}

Tingkat VO2 maksimal pada perlakuan 1 dengan rata-rata sebesar 
$34,59 \pm 3,16 \mathrm{ml} / \mathrm{kg} / \mathrm{min}$, pada perlakuan

2 dengan rata-rata sebesar $36,32 \pm 3,77$

$\mathrm{ml} / \mathrm{kg} / \mathrm{min}$ dan pada perlakuan 3 dengan rata-rata sebesar $38,54 \pm 5,13 \mathrm{ml} / \mathrm{kg} / \mathrm{min}$.

Berdasarkan ketiga perlakuan yang telah dilakukan, nilai VO2 maksimal paling baik diperoleh pada perlakuan 3 dengan rata-rata 38,54 (tabel 3).

Tabel 3. Tingkat VO2 maksimal remaja putri peserta ekstrakurikuler bola basket pada setiap perlakuan

\begin{tabular}{lll} 
VO2 & $\mathrm{N}$ & Mean \pm SD \\
\hline Perlakuan 1 & 8 & $34,59 \pm 3,16$ \\
Perlakuan 2 & 8 & $36,32 \pm 3,77$ \\
Perlakuan 3 & 8 & $38,54 \pm 5,13$ \\
Total & 24 & $36,48 \pm 4,26$ \\
\hline
\end{tabular}

Keterangan :

Perlakuan $1=$ Pemberian air biasa

Perlakuan $2=$ Pemberian air karbohidrat 6\%

Perlakuan 3 = Pemberian air kelapa muda

\section{Perbandingan Tingkat Dehidrasi}

Remaja Putri Peserta Ekstrakurikuler

\section{Bola Basket Pada Berbagai Perlakuan}

\section{Hasil analisis Shapiro-Wilk} menunjukkan bahwa data tingkat dehidrasi tidak berdistribusi normal ( $p=$ 0,047) sehingga digunakan uji KruskallWallis. Terdapat perbedaan tingkat dehidrasi remaja putri peserta ekstrakulikuler bola basket dengan berbagai perlakuan $(p=0,0001)$. Berdasarkan dari hasil uji KruskallWallis, menunjukkan terdapat perbedaan tingkat dehidrasi pada ketiga perlakuan, sehingga dilanjutkan dengan uji Mean-
Whitney. Berdasarkan uji Mean-Whitney, terdapat perbedaan yang signifikan antar semua perlakuan. Perbedaan perlakuan 1 dan perlakuan $2(p=0,005)$, perlakuan 1 dan perlakuan $3(p=0,001)$ serta perlakuan 2 dan perlakuan $3(p=0,009)$ (gambar 1).

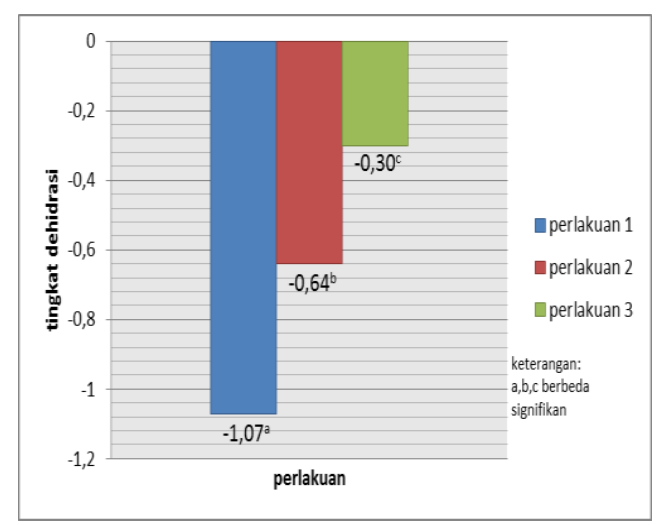

Gambar 1. Diagram perbandingan median tingkat dehidrasi pada ketiga perlakuan

Keterangan :

Perlakuan $1=$ Pemberian air biasa Perlakuan $2=$ Pemberian air karbohidrat $6 \%$ Perlakuan 3 = Pemberian air kelapa muda

Berdasarkan penelitian yang telah dilakukan, subjek mengalami peningkatan nilai median tingkat dehidrasi dari -1,07 pada perlakuan 1 (air biasa) menjadi -0,64 pada perlakuan 2 (air kabohidrat 6\%) dan meningkat menjadi 0,30 pada perlakuan 3 (air kelapa hijau muda). Pemberian perlakuan 3 menunjukkan nilai median tingkat dehidrasi paling baik yaitu -0,30 sehingga dapat digunakan sebagai cairan rehidrasi pada subjek remaja putri peserta ekstrakurikuler bola basket. 
Hasil penelitian ini menunjukkan bahwa pemilihan jenis cairan mempengaruhi tingkat dehidrasi yang dialami subjek penelitian. Pemberian minuman pada perlakuan 1 yaitu dengan menggunakan air biasa sebanyak $600 \mathrm{ml}$ selama latihan bola basket 60 menit menunjukkan hasil minimal dehidrasi. Minimal dehidrasi yang terjadi berkaitan dengan kondisi keseimbangan cairan di dalam tubuh, dimana ketika subjek hanya mengkonsumsi air biasa selama latihan maka besar kemungkinan subjek mengalami hiponatremi karena penurunan kosentrasi plasma natrium. (Azahar, 2011) Jumlah cairan yang dikonsumsi adalah jumlah minimal dari anjuran konsumsi cairan berdasarkan penelitian sebelumnya pada periode saat latihan, yaitu 100-150 ml per 10-15 menit. (Putriana dan Dieny, 2014)

Pemilihan jenis cairan yang kurang tepat akan mempengaruhi proses metabolisme dan keseimbangan cairan dalam tubuh. Konsumsi air biasa selama latihan dapat berakibat terjadinya hiponatremi dalam tubuh, dimana jumlah air dan natrium tidak seimbang. Ketidakseimbangan air dan natrium dalam darah dapat menyebabkan darah menjadi encer, sehingga jumlah oksigen dan nutrisi yang akan diedarkan ke seluruh tubuh menjadi berkurang. Kekurangan asupan oksigen dan nutrisi dalam tubuh dapat mengakibatkan organ tubuh tidak mampu berfungsi secara maksimal sehingga terjadi gangguan pada proses metabolisme tubuh. Dampak lain dari hiponatremi adalah peningkatan denyut jantung, pusing, terkadang disertai dengan kram otot, lelah dan lemas. (Institute, 2010)

Berdasarkan penelitian sebelumnya yang dilakukan oleh Casa, et al tahun 2000 bahwa penggunaan cairan karbohidrat sebesar 6-8\% mampu memberikan asupan energi yang mudah diserap tubuh serta meningkatkan penyerapan elektrolit di dalam tubuh sehingga keseimbangan cairan dan elektrolit tersebut dapat terjaga. (Casa et al., 2000)

Hasil yang tunjukkan pada perlakuan 3 yaitu dengan pemberian air kelapa muda menunjukkan subjek dalam kategori well hydrated atau dapat terhidrasi serta memiliki nilai yang lebih baik dibandingkan dengan perlakuan 2 . Penggunaan air kelapa muda untuk proses rehidrasi karena sifat dan komposisi air kelapa muda yang mirip dengan cairan tubuh (isotonik) sehingga mudah untuk diserap dan mampu menjaga keseimbangan cairan dalam tubuh. Berdasarkan penelitian sebelumnya, penggunaan cairan rehidrasi air kelapa muda mempunyai nilai yang tertinggi pada sensasi setelah minum (after taste) 
dan jumlah yang diminum oleh atlet futsal dibandingkan dengan air kelapa komersil, isotonik komersil dan air kemasan. (Kailaku, 2016) Air kelapa muda juga memiliki indeks rehidrasi yang tertinggi jika dibandingkan dengan sport drink atau minuman penambah stamina (Syam, 2014).

\section{Perbandingan VO2 Maksimal

Remaja Putri Peserta \\ Ekstrakurikuler Bola Basket Pada \\ Berbagai Perlakuan}

Hasil penelitian menunjukkan bahwa data berdistribusi normal ( $p=$ 0,732) sehingga digunakan uji One Way Anova. Tidak terdapat perbedaan VO2 maksimal remaja putri peserta ekstrakulikuler bola basket dengan berbagai perlakuan $(p=0,180)$ (gambar 2).

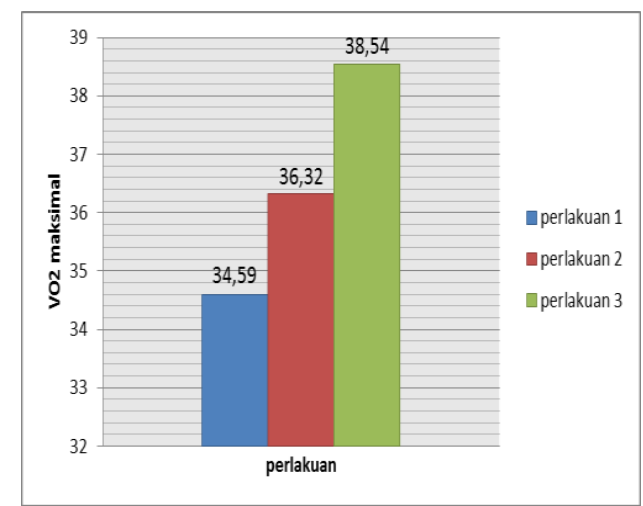

Gambar 2. Diagram rata-rata VO2 Keterangan : maksimal pada ketiga perlakuan

Perlakuan $1=$ Pemberian air biasa Perlakuan $2=$ Pemberian air karbohidrat $6 \%$ Perlakuan $3=$ Pemberian air kelapa muda
Berdasarkan hasil uji statistik menunjukkan hasil bahwa tidak terdapat perbedaan yang bermakna pada hasil VO2 maksimal untuk setiap perlakuan yang telah dilakukan $(p=0,180)$. Hasil yang diperoleh pada penelitian ini berbeda dengan hasil penelitian sebelumnya, dimana terdapat perbedaan nilai rata-rata $\mathrm{VO} 2$ maksimal pada kelompok perlakuan yang diberikan minuman isotonik dan kelompok kontrol yang diberikan air biasa. Perbedaan dengan penelitian sebelumnya adalah subjek diukur nilai VO2 maksimal sebelum dan sesudah diberi perlakuan. (Azizah, Biworo dan Asnawati, 2015)

Nilai VO2 maksimal dapat dijadikan analisa output dari program latihan yang telah dibuat serta menjadi indikator kesehatan atau kebugaran dari atlet tersebut. Atlet yang mempunyai nilai VO2 maksimal dalam kategori tinggi akan mampu melakukan aktifitas atau kegiatan olahraga yang lebih baik daripada atlet yang memiliki nilai VO2 maksimal lebih rendah. Faktor kebugaran dan VO2 maksimal seorang atlet ditentukan oleh berbagai faktor, diantaranya kodisi fisiologis paru jantung, kadar hemoglobin, jenis kelamin, komposisi tubuh, usia, suhu lingkungan dan keadaan latihan.

Faktor yang mempengaruhi nilai 
VO2 maksimal pada penelitian ini, diantaranya adalah suhu lingkungan, keadaan latihan dan jarak pengambilan nilai VO2 maksimal. (Septian Nosa, 2013) Pengambilan data dengan berbagai perlakuan dilaksanakan pada hari yang berbeda-beda. Suhu lingkungan pada saat penelitian dipengaruhi oleh cuaca, dimana pada saat perlakuan terdapat perbedaan cuaca. Peneliti tidak mampu untuk meminimalisir faktor perancu terkait suhu lingkungan dikarenakan perbedaan cuaca. Secara tidak langsung, perubahan suhu yang terjadi akan mempengaruhi proses metabolisme di dalam tubuh sehingga akan berpengaruh terhadap kerja kardiovaskuler dan akhirnya berpengaruh terhadap nilai VO2 maksimal yang dapat dicapai. (Septian Nosa, 2013)

Keadaan latihan juga dapat menjadi faktor penentu nilai VO2 maksimal yang mampu didapatkan oleh seseorang. VO2 maksimal ini tidak terpaku pada nilai tertentu melainkan dapat berubah sesuai tingkat dan intensitas aktifitas fisik yang dilakukan. Contohnya, bed-rest lama dapat menurunkan VO2 maksimal antara 15$25 \%$, namun latihan fisik yang dilakukan secara intens atau teratur dengan memperhatikan lama waktu istirahat dapat meningkatkan nilai VO2 maksimal. (Septian Nosa, 2013). Jarak waktu penelitian yang terlalu dekat juga mempengaruhi hasil pengukuran VO2 maksimal, dimana subjek akan cenderung mengetahui pola dan jeda waktu yang digunakan pada saat beep test sehingga subjek mampu menjaga irama lari yang dilakukan ketika tes lebih baik dibandingkan tes pada hari sebelumnya. Pelaksanaan beep test dianjurkan untuk dilaksanakan minimal seminggu 3 kali atau jeda pelaksanaan selama 48 jam (Mardian, 2013).

\section{KESIMPULAN}

Berdasarkan penelitian yang telah dilakukan, dapat disimpulkan sebagai berikut: tingkat dehidrasi yang terjadi selama proses penelitian menunjukkan perbedaan yang signifikan pada setiap perlakuan $(p=$ 0,0001) dengan tingkat dehidrasi yang paling baik pada pemberian isotonik alami air kelapa hijau muda (median -0,30); VO2 maksimal yang dinilai selama proses penelitian tidak menunjukkan perbedaan pada setiap perlakuan $(p=0,180)$.

\section{SARAN}

Diperlukan edukasi tentang pemilihan jenis, jumlah dan waktu konsumsi cairan selama periode latihan kepada atlet. Dianjurkan untuk mengkonsumsi cairan isotonik alami (air kelapa hijau muda) $100-150 \mathrm{ml}$ per 10-15 menit 
selama proses latihan agar subjek tidak mengalami dehidrasi selama latihan. Diperlukan penelitian lebih lanjut dengan jumlah subjek penelitian yang lebih banyak dan waktu penelitian yang cukup dengan memperhatikan faktor pemenuhan cairan selama periode latihan, suhu lingkungan dan kelembaban udara (lebih baik dilakukan indoor) serta pengamatan kadar $\mathrm{Hb}$ subjek.

\section{DAFTAR PUSTAKA}

Abdullah, S. (2015) Tim Basket Putri Indonesia Pastikan Medali perak.

Agus, A. (2012) Olahraga Kebugaran jasmani sebagai suatu pengantar. Padang: Penerbit Sukabina Press.

Alim, A. (2012) Persepsi Atlet Terhadap Kebutuhan Cairan (Hidrasi) Saat Latihan Fisik dan Recovery pada Unit Kegiatan Mahasiswa Olahraga Universitas Negeri Yogyakarta. Universitas Negeri Yogyakarta.

Azahar, N. B. B. (2011) Tingkat Pengetahuan Mahasiswa FK USU Angkatan 2007 Mengenai Manfaat Konsumsi Minuman Isotonik Pada Aktifitas Olahraga. Universitas Sumatera Utara.

Azizah, Biworo, A. and Asnawati (2015) 'Hubungan Minuman Isotonik Dengan Konsumsi Oksigen Maksimal Pada Mahasiswa Jpok Unlam Banjarbaru', Berkala Kedokteran Unlam.

Casa, D. J. et al. (2000) 'National Athletic Trainers' Association Position Statement: Fluid Replacement for
Athletes', Journal of Athletic Training.

Institute, N. N. (2010) Fokus Nutrisi Olahraga.

Kailaku, S. I. (2016) Pengaruh Intervensi Produk Minuman Isotonik Air Kelapa dari Proses Ultrafiltrasi dan Ultraviolet Terhadap Rehidrasi dan Pemulihan Atlet Futsal Remaja Putri, IPB.

Mardian, Y. (2013) Mengenal VO2 Maksimal.

Nauli, S. N. P. (2006) Analisis Persepsi, Konsumsi dan Kepuasan Terhadap Minuman Isotonik Pada Atlet Bola Basket. Institut Pertanian Bogor.

Nigara, M. (2015) Sea Games 2015 Gagal, Mundurkah Imam Nahrawi? Available at: http://sports.sindonews.com/read/ 1012913/51/sea-games-2015gagal-mundurkah-imam-nahrawi1434369658 (Accessed: 19 April 2016).

Putriana, D. and Dieny, F. F. (2014) 'Konsumsi Cairan Periode Latihan dan Status Hidrasi Setelah Latihan Pada Atlet Sepak Bola Remaja', Journal of Nutrition College. doi: 10.14710/jnc.v3i4.6869.

Septian Nosa, A. S. (2013) 'Survei Tingkat Kebugaran Jasmani pada Pemain Persatuan Sepakbola Indonesia Lumajang', Jurnal Prestasi Olahraga.

Syam, R. V. A. (2014) Studi Pembuatan Minuman Isotonik Alami Berenergi Tinggi. Universitas Hassanudin. 